\title{
OPTIMISING THE EFFECT OF STIMULANTS ON CITRIC ACID PRODUCTION FROM COCOYAM STARCH USING ASPERGILLUS NIGER
}

\author{
N. A. Amenaghawon ${ }^{1,}$,, 0. U. Osazuwa ${ }^{2}$, 0. E. Ebewele ${ }^{3}$ \\ 1, 2,3 Department of Chemical EngineERING, University of Benin, PMB 1154, Benin City, Edo State, NiGERIA \\ Email addresses' andrew.amenaghawon@uniben.edu, ${ }^{2}$ osarieme.osazuwa@uniben.edu, \\ 3eboseremen.ebewele@uniben.edu
}

\begin{abstract}
Additives such as low molecular weight alcohols, trace metals, phytate, lipids etc have been reported to stimulate citric acid production. Hence the objective of this study was to investigate the effect of stimulating the metabolic activity of Aspergillus niger for the purpose of improved citric acid production from cocoyam starch. $A$ threevariable, three-level Box-Behnken design (BBD) was used to develop a statistical model to study the effects of Zinc (II) ion, Iron (III) ion and methanol on the production of citric acid. Response surface methodology (RSM) was used to optimise the effects of these stimulants. The results of analysis of variance (ANOVA) carried out on the model showed that the model was statistically significant $(p<0.0001)$ and did not show lack of fit $\left(R^{2}=0.997\right)$. The results also showed that citric acid production increased when the levels of zinc and methanol were increased. Intermediate levels of iron were required to produce citric acid at optimum levels. Results obtained from RSM showed that the optimum levels of zinc, iron and methanol were $4.5 \mathrm{~g} / \mathrm{L}, 6.87 \mathrm{~g} / \mathrm{L}$ and $3.0 \% \mathrm{v} / \mathrm{v}$ respectively. Under these conditions, the maximum citric acid concentration was obtained as $108 \mathrm{~g} / \mathrm{L}$. Validation of the model indicated no significant difference between predicted and experimental values.
\end{abstract}

Keywords: Optimisation, Citric acid, Cocoyam, Fermentation, Methanol

\section{INTRODUCTION}

Citric acid is a tri-carboxylic organic acid which finds a lot of uses in the food, beverage, pharmaceutical, chemical, cosmetic and other industries for applications such as acidulation, anti-oxidation, flavour enhancement, preservation, plasticizer and as a synergistic agent $[1,2]$. Due to the increasing demand of citric acid, it has been established that producing citric acid from synthetic or chemical methods cannot compete favourably with biotechnological means [3]. Hence, a large proportion of the world's demand for citric acid is satisfied from biotechnological means specifically submerged microbial fermentation of sucrose or molasses using the filamentous fungus, Aspergillus niger [4]. Aspergillus niger is the preferred fermenting organism for commercial scale production of citric acid because it has the capacity to ferment a wide range of cheap substrates and it can produce high yields of citric acid even at low $\mathrm{pH}$ values without the production of unwanted by products [5].
Nigeria is the world's largest producer of cocoyam, accounting for about $37 \%$ of total world output [6]. However, as a result of lack of proper facilities for the storage of the cocoyam tubers, large amounts in the order of millions of tons are reportedly destroyed through pest infestation, deterioration, physical damage to the tubers, pilfering etc [7]. Since the cocoyam tuber is rich in starch, the starch can be hydrolysed and fermented to produce value added products such as bioalcohols and citric acid, thereby recovering the losses resulting from wastage and expanding the usage range of these tubers [8].

The production of citric acid using Aspergillus niger has been reported to be influenced by the medium composition such as the concentration of carbon, nitrogen, phosphorous, potassium, trace elements (zinc, iron, manganese) and stimulants such as low molecular weight alcohol [9]. Several reports have shown the stimulatory effects of additives on citric acid production [10-12]. To improve citric acid production, stimulators such as trace metals, low 
molecular weight alcohols, phytate, lipids etc have been used [5]. Thus, citric acid productivity by Aspergillus niger could be further improved by optimising the medium composition as well as the effect of the stimulants. Experimental design method coupled with response surface methodology (RSM) has been reported to be very effective in achieving this and it has been successfully applied to the optimisation of many bioprocesses [13-16].

Hence the objective of this study was to optimise the effect of stimulants on citric acid production from cocoyam starch using Aspergillus niger. A three variable Box-Behnken design for response surface methodology was used to study the simultaneous effect of three independent variables $\left(\mathrm{Fe}^{3+}, \mathrm{Zn}^{2+}\right.$ and $\mathrm{CH}_{3} \mathrm{OH}$ concentration) for optimum citric acid production.

\section{MATERIALS AND METHODS}

\subsection{Cocoyam Starch Preparation}

Cocoyam tubers were obtained from Benin City, Edo State, Nigeria.The cocoyam tuber is rich in carbohydrate containing abouit $77.9 \%$ starch making it an ideal substrate for producing citric acid [77]. The tubers were washed in clean water to remove the adhering dirt after which they were peeled manually and crushed using a mill. The crushed pulp was sieved with a sieve of Teflon cloth. The starch obtained was allowed to settle for about $12 \mathrm{~h}$. It was decanted and the starch cake obtained was oven dried. The dried starch was then packed in a clean container for storage [7].

\subsection{Two Step Enzymatic Hydrolysis of Cocoyam Starch}

A solution of starch was prepared by weighing $20 \mathrm{~g}$ of starch into $80 \mathrm{~mL}$ of a solution containing $40 \mathrm{ppm}$ $\mathrm{Ca}^{2+}$. The $\mathrm{pH}$ was adjusted to 6.5 using citratephosphate buffer. The slurried starch was gelatinized by heating the mixture to $97{ }^{\circ} \mathrm{C}$ for 10 minutes after which $1 \%(\mathrm{v} / \mathrm{v})$ of bacterial $\alpha$-amylase was added for liquefaction to take place at a temperature $61{ }^{\circ} \mathrm{C}$ and a $\mathrm{pH}$ of 6.5 for 55 minutes. Enzyme activities were stopped by heating the mixture to boil. The final mixture was centrifuged at 10,000 rpm for 10 minutes and the supernatants were analyzed for reducing sugar. The liquefied starch was later subjected to saccharification using fungal glucoamylase at a temperature of $52^{\circ} \mathrm{C}$ and a $\mathrm{pH}$ of 4.5 for 44 minutes and the mixture was treated as stated above [7].

\subsection{Microorganism, Inoculum Preparation and Fermentation}

Aspergillus niger ATCC 9142, obtained from the Biotechnology division of the Federal Institute of Industrial Research Oshodi (FIRO), Lagos, Nigeria was used throughout the study as the fermenting organism. Conidia suspensions of fungal strains were obtained from cultures grown on potato dextrose agar slants at $30^{\circ} \mathrm{C}$ for 5 to 7 days. The spores were washed with sterilised $0.8 \%$ Tween 80 solution by shaking vigorously for 1 minute. Spores were counted with a haemocytometer to obtain approximately $2 \times 10^{7}$ spores/mL. The composition $(\mathrm{g} / \mathrm{L}$ ) of the fermentation medium used for citric acid production was as described by Lotfy et al. [18]. $\mathrm{NaNO}_{3}, 4.0 ; \mathrm{KH}_{2} \mathrm{PO}_{3}, 1.0$; $\mathrm{MgSO}_{4.7 \mathrm{H}_{2} \mathrm{O}}, 0.23 ; \mathrm{FeCl}_{3}, 0.02 ; \mathrm{ZnSO}_{4}, 0.0012$; $\mathrm{MnCl}_{2} \cdot \mathrm{H}_{2} \mathrm{O}, 0.0012$.The $\mathrm{pH}$ of the culture medium was adjusted to 5.5 by adding a sterile solution of sulphuric acid. Surface fermentation was carried out in $250 \mathrm{~mL}$ Erlenmeyer flasks. The flask containing the fermentation medium was inoculated with $0.5 \mathrm{~mL}$ of the inoculum and then incubated at $30^{\circ} \mathrm{C}$.

\subsection{Analytical Methods}

The concentration of citric acid produced during fermentation was determined using the pyridineacetic anhydride method as reported by Marrier and Boulet [19]. This was accomplished by adding $1 \mathrm{~mL}$ of the filtered fermentation broth along with $1.30 \mathrm{~mL}$ of pyridine and $5.7 \mathrm{~mL}$ of acetic anhydride in a test tube. The test tube was then placed in a water bath at $32{ }^{\circ} \mathrm{C}$ for $30 \mathrm{~min}$. The absorbance of the sample was measured at $405 \mathrm{~nm}$ using a UV-Vis spectrophotometer (PG Instruments model T70). The concentration of citric acid in the sample was determined from a citric acid calibration curve which was prepared from known concentrations of citric acid.

\subsection{Design of Experiment}

A three variable Box Behnken design (BBD) for response surface methodology was used to develop a statistical model for the fermentation process. The levels of variables optimised are shown in Table 1 . The experimental design was developed using Design Expert $^{\circledR}$ 7.0.0 (Stat-ease, Inc. Minneapolis, USA). The coded and actual values of the independent variables were calculated as follows.

$$
X_{i}=\frac{X_{i}-X_{o}}{\Delta X_{i}}
$$


Where $x_{i}$ and $X_{i}$ are the coded and actual values of the independent variable respectively. $X_{O}$ is the actual value of the independent variable at the centre point and $\Delta X_{i}$ is the step change in the actual value of the independent variable. The following generalised second order polynomial equation was used to estimate the response of the dependent variable.

$Y_{i}=b_{o}+\sum b_{i} X_{i}+\sum b_{j} X_{i} X_{j} \sum b_{i i} X_{i}^{2}+e_{i}$

$Y_{i}$ is the dependent variable or predicted response, $x_{i}$ and $X_{j}$ are the independent variables, $b_{o}$ is the offset term, $b_{i}$ and $b_{i j}$ are the single and interaction effect coefficients and $e_{i}$ is the error term.

Table 1: Coded and actual levels of the factors for three factor Box-Behnken design

\begin{tabular}{lcccc}
\hline \multirow{2}{*}{$\begin{array}{l}\text { Independent } \\
\text { Variable }\end{array}$} & Symbols & \multicolumn{3}{c}{$\begin{array}{c}\text { Coded and Actual } \\
\text { level }\end{array}$} \\
\cline { 3 - 5 } & & -1 & 0 & 1 \\
\hline $\mathrm{CH}_{3} \mathrm{OH} \mathrm{( \% v/v)}$ & $\mathrm{X}_{1}$ & 0 & 1.5 & 3 \\
$\mathrm{Fe}^{3+}(\mathrm{g} / \mathrm{L})$ & $\mathrm{X}_{2}$ & 0 & 5 & 10 \\
$\mathrm{Zn}^{2+}(\mathrm{g} / \mathrm{L})$ & $\mathrm{X}_{3}$ & 0 & 2.25 & 4.5 \\
\hline
\end{tabular}

\section{RESULTS AND DISCUSSION}

\subsection{Statistical Analysis}

The Box Behnken design resulted in 17 experimental runs as shown in Table 2. The response variable was chosen as the citric acid concentration. Citric acid concentration was chosen as the response because it is the most convenient measure of the amount of citric acid produced during fermentation. Equation (3) is the quadratic statistical model in terms of actual variables that was obtained after applying multiple regression analysis to the experimental data presented in Table 2.

$$
\begin{aligned}
Y=84.07-22.74 X_{1}+0.582 X_{2}-16.47 X_{3} \\
-0.22 X_{1} X_{2}+5.48 X_{1} X_{3}+1.16 X_{2} X_{3} \\
+5.52 X_{1}^{2}-0.37 X_{2}^{2}+1.23 X_{3}^{2}
\end{aligned}
$$

The values of citric acid concentration predicted by Equation (3) are also presented in Table 2. The results of analysis of variance (ANOVA) carried out to determine the fit of the statistical model are presented in Tables 3 and 4. The ANOVA results showed that the model was statistically significant with a very low $p$ value $(p<0.0001)$ as shown in Table 3 . The model did not show lack of fit as seen from the "lack of fit" $p$ value of 0.657 . The first order main effects of methanol, iron and zinc concentration were significant as evident from their respective $p$ values. This suggests that changes in the levels of these stimulants could affect the growth rate of the fungal cells as well as citric acid production [20]. The parity plot comparing experimental values of the response and those predicted by the statistical model showed that there was an acceptable level of correlation between the experimental and model predicted results as shown in Figure 1. This is evident from the fact that the data points all clustered around the $45^{\circ}$ diagonal line showing that there was minimal deviation between experimental and predicted values thus indicating optimal fit of the model.

Statistical information for ANOVA showed that the model had a high coefficient of determination $\left(\mathrm{R}^{2}\right)$ as shown in Table 4. This shows that the model was able to adequately represent the relationship between the chosen factors (methanol, iron (III) and zinc (II) concentration) and the response (citric acid concentration).

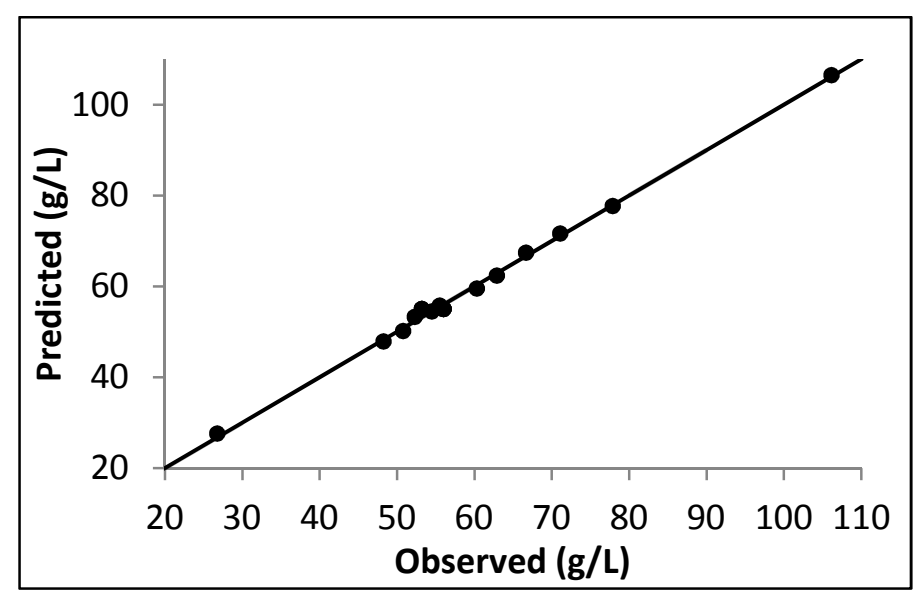

Figure 1: Comparison between predicted and observed values of citric acid concentration

An $\mathrm{R}^{2}$ value of 0.997 means that the model was able to explain $99.7 \%$ of the variability observed in the response. The standard deviation was observed to be relatively small compared to the mean further validating the model. The coefficient of variation (CV) was obtained as 2.35 . This value gives an indication of the degree of precision with which the treatments were carried out [21]. The relatively low value of CV obtained showed that the treatments were carried out with high precision and reliability [22]. The Adequate precision for the model was obtained as 73.95 showing that the model can be used to navigate the design space [23]. 
Table 2: Three variable Box-Behnken design for citric

\begin{tabular}{|c|c|c|c|c|c|c|c|}
\hline \multirow{3}{*}{ Runs } & \multicolumn{6}{|c|}{ Factors } & \multirow{3}{*}{$\begin{array}{c}\text { Responses } \\
\begin{array}{c}\text { Citric acid } \\
(\mathrm{g} / \mathrm{l})\end{array} \\
\text { Observed }\end{array}$} \\
\hline & \multicolumn{3}{|c|}{ Coded levels } & \multicolumn{3}{|c|}{ Actual Values } & \\
\hline & $\mathrm{X}_{1}$ & $\mathrm{X}_{2}$ & $\mathrm{X}_{3}$ & $\mathrm{X}_{1}$ & $\mathrm{X}_{2}$ & $\mathrm{X}_{3}$ & \\
\hline 1 & 1 & 1 & 0 & 3 & 10 & 2.25 & 52.34 \\
\hline 2 & 0 & 1 & -1 & 1.5 & 10 & 0 & 71.14 \\
\hline 3 & 0 & 0 & 0 & 1.5 & 5 & 2.25 & 48.31 \\
\hline 4 & 0 & 0 & 0 & 1.5 & 5 & 2.25 & 60.38 \\
\hline 5 & 0 & 0 & 0 & 1.5 & 5 & 2.25 & 77.92 \\
\hline 6 & 1 & 0 & -1 & 3 & 5 & 0 & 55.58 \\
\hline 7 & -1 & 0 & -1 & 0 & 5 & 0 & 54.57 \\
\hline 8 & 0 & 0 & 0 & 1.5 & 5 & 2.25 & 106.19 \\
\hline 9 & -1 & 0 & 1 & 0 & 5 & 4.5 & 62.98 \\
\hline 10 & -1 & -1 & 0 & 0 & 0 & 2.25 & 26.80 \\
\hline 11 & 1 & 0 & 1 & 3 & 5 & 4.5 & 50.85 \\
\hline 12 & 0 & 1 & 1 & 1.5 & 10 & 4.5 & 66.75 \\
\hline 13 & -1 & 1 & 0 & 0 & 10 & 2.25 & 56.06 \\
\hline 14 & 1 & -1 & 0 & 3 & 0 & 2.25 & 53.26 \\
\hline 15 & 0 & -1 & -1 & 1.5 & 0 & 0 & 56.06 \\
\hline 16 & 0 & -1 & 1 & 1.5 & 0 & 4.5 & 53.26 \\
\hline 17 & 0 & 0 & 0 & 1.5 & 5 & 2.25 & 56.06 \\
\hline
\end{tabular}

Table 3: ANOVA for quadratic model for citric acid

\begin{tabular}{lcllll}
\multicolumn{6}{c}{ production } \\
\hline Source & $\begin{array}{l}\text { Sum of } \\
\text { squares }\end{array}$ & $\mathrm{df}$ & $\begin{array}{l}\text { Mean } \\
\text { square }\end{array}$ & $\mathrm{F}$ value & $\mathrm{p}$-value \\
\hline Model & 4180.6 & 9 & 464.51 & 239.95 & $<0.0001$ \\
$\mathrm{X}_{1}$ & 452.46 & 1 & 452.46 & 233.72 & $<0.0001$ \\
$\mathrm{X}_{2}$ & 153.72 & 1 & 153.72 & 79.402 & $<0.0001$ \\
$\mathrm{X}_{3}$ & 379.27 & 1 & 379.27 & 195.91 & $<0.0001$ \\
$\mathrm{X}_{1} \mathrm{X}_{2}$ & 11.303 & 1 & 11.303 & 5.8384 & 0.0463 \\
$\mathrm{X}_{1} \mathrm{X}_{3}$ & 1367.7 & 1 & 1367.7 & 706.51 & $<0.0001$ \\
$\mathrm{X}_{2} \mathrm{X}_{3}$ & 678.52 & 1 & 678.52 & 350.49 & $<0.0001$ \\
$\mathrm{X}_{1}{ }^{2}$ & 648.61 & 1 & 648.61 & 335.04 & $<0.0001$ \\
$\mathrm{X}_{2}{ }^{2}$ & 364.82 & 1 & 364.82 & 188.45 & $<0.0001$ \\
$\mathrm{X}_{3}{ }^{2}$ & 162.57 & 1 & 162.57 & 83.973 & $<0.0001$ \\
Residual & 13.55 & 7 & 1.9359 & & \\
Lack of Fit & 4.123 & 3 & 1.3744 & 0.5831 & 0.657 \\
Pure Error & 9.428 & 4 & 2.357 & & \\
Cor Total & 4194. & 16 & & & \\
\hline
\end{tabular}

Table 4: Statistical information for Box-Behnken design

\begin{tabular}{ll}
\hline Variable & Value \\
\hline Standard deviation & 1.39 \\
Mean & 59.32 \\
C.V.\% & 2.35 \\
$\mathrm{R}^{2}$ & 0.997 \\
Predicted R $^{2}$ & 0.98 \\
Adeq Precision & 73.95 \\
\hline
\end{tabular}

\subsection{Optimisation of Citric Acid Production}

Figures 2 to 4 represent the response surfaces describing the interactive effects of the tested variables on the response. Citric acid production was positively influenced by $\mathrm{Zn}^{2+}$ as shown in Figure 2 . Citric acid concentration was observed to increase with increase in the concentration of $\mathrm{Zn}^{2+}$. This trend could be attributed to the stimulating effect of $\mathrm{Zn}^{2+}$ on the fungal cells. Citric acid production was inhibited by $\mathrm{Fe}^{3+}$ as shown by the decrease in citric acid concentration when the concentration of $\mathrm{Fe}^{3+}$ was increased. This trend was observed at low levels of $\mathrm{Zn}^{2+}$. However, at high levels of $\mathrm{Zn}^{2+}$, the inhibitory effect of $\mathrm{Fe}^{3+}$ was suppressed such that optimum levels of citric acid production was recorded at intermediate levels of $\mathrm{Fe}^{3+}$. A similar trend was reported by Majolli and Aguirre [24]. A search of the literature revealed that there is no generally established trend with respect to the effects of these traces metals. Some studies have reported stimulatory effects while others have reported inhibitory effects [25]. Nevertheless, it is well established that trace metal ions particularly divalent metal ions such as zinc, iron, manganese etc can significantly affect citric acid production by Aspergillus niger [26]. Hence, Soccol et al. [27] advised that it is necessary to take the interdependence of the fermentation medium constituents into account and that citric acid production could be improved only if a strict control of the trace metal availability is achieved.

Low molecular weight alcohols such as methanol and ethanol have been known to positively influence citric acid production [5]. Figure 3 shows the effect of the interaction between methanol concentration and $\mathrm{Fe}^{3+}$ concentration on citric acid production. Citric acid production increased generally in the presence of methanol. A similar trend has been reported by previous researchers. Alben and Erkmen [28] reported that the addition of methanol at a concentration of 1 to $4 \%$ resulted in a significant increase in the amount of citric acid produced by Aspergillus niger in spent grain liquor in brewery wastes. El-Holi and Al-Delaimy [29] attributed these observations to the reduction of the inhibitory effect of metal ions. They also suggested that methanol could also have served as carbon substrate for the microbial cells. It has also been suggested that the addition of methanol under optimised conditions increases the permeability of the cell membrane of Aspergillus niger which subsequently increases the transfer of nutrients, which in turn increases the secretion of 
citric acid across the cell membrane [30]. Figure 3 also shows that the inhibitory effect of $\mathrm{Fe}^{3+}$ was suppressed in the presence of methanol.

The results presented in Figure 4 corroborated those presented in Figures 2 and 3 with respect to the trends

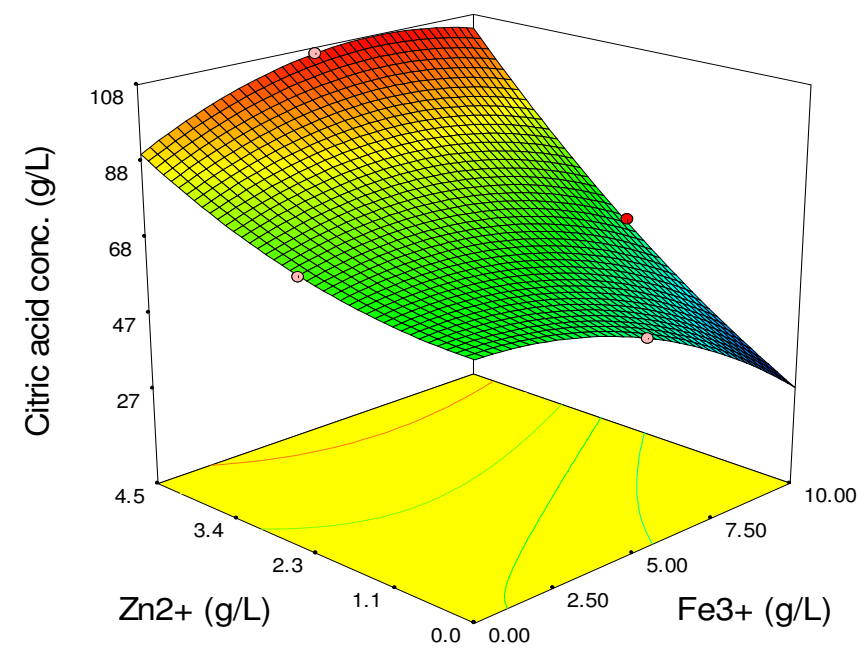

observed for $\mathrm{Zn}^{2+}$ and methanol respectively. The optimisation of the statistical model resulted in the selection of the optimum fermentation conditions and their respective levels.

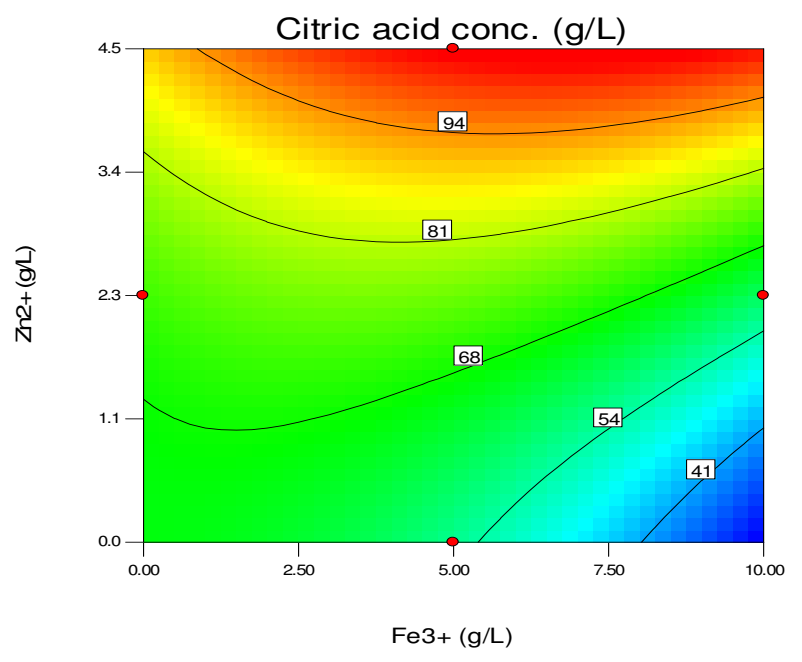

Figure 2: Response surface and corresponding contour plot showing the effect of Zinc (II) and iron III
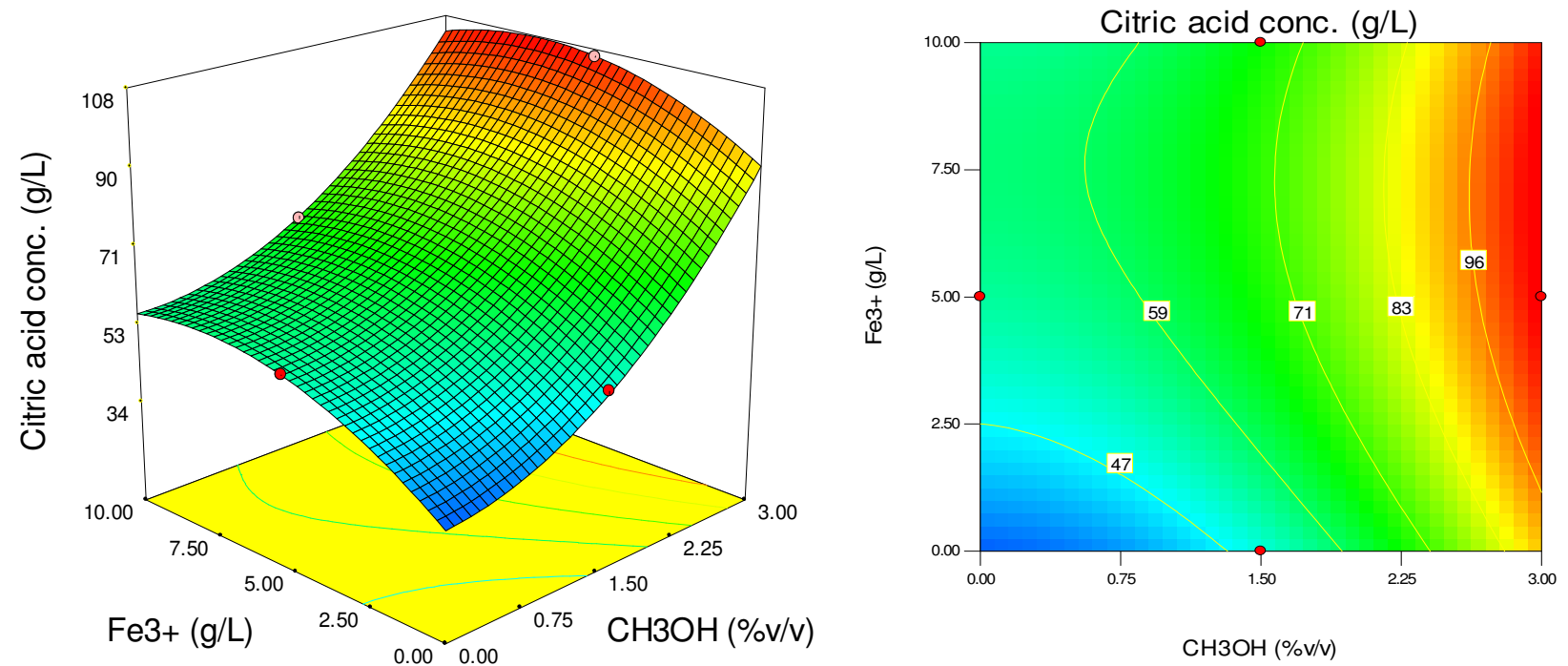

Figure 3: Response surface and corresponding contour plot showing the effect of iron (III) and methanol
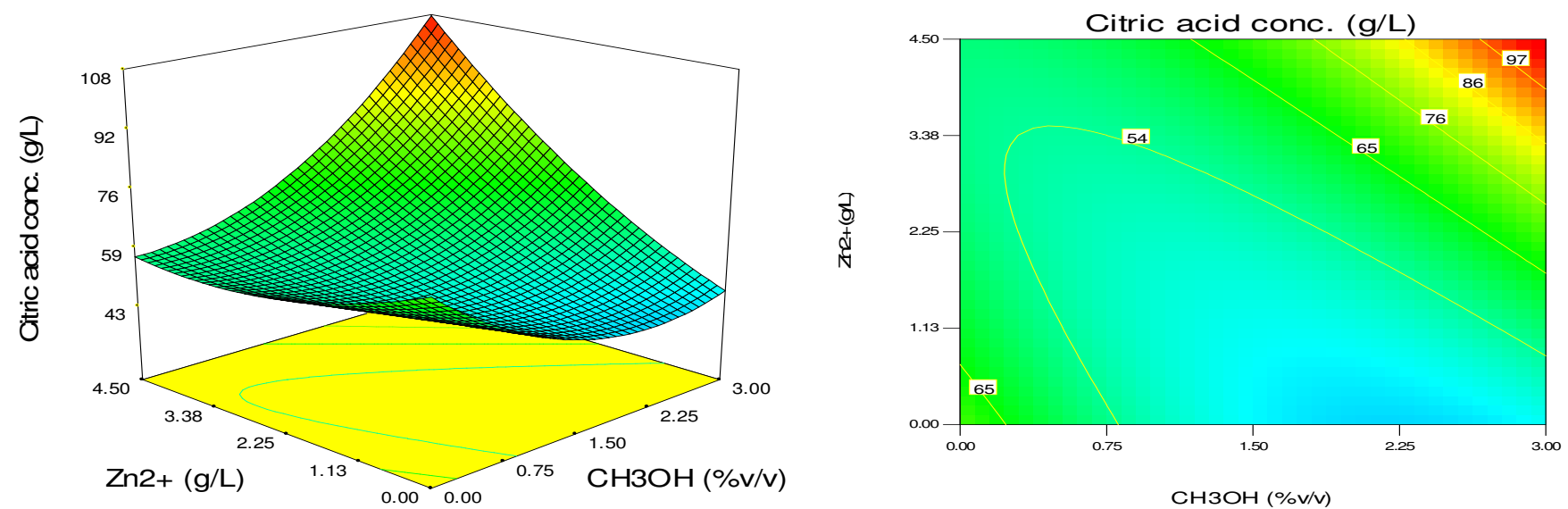

Figure 4: Response surface and corresponding contour plot showing the effect of Zinc (II) and methanol 
The maximum citric acid concentration predicted by the model was $108 \mathrm{~g} / \mathrm{L}$. The final optimised conditions for the production citric acid as obtained from RSM were $\mathrm{Zn}^{2+}$ concentration of $4.5 \mathrm{~g} / \mathrm{L}, \mathrm{Fe}^{3+}$ concentration of $6.87 \mathrm{~g} / \mathrm{L}$ and $\mathrm{CH}_{3} \mathrm{OH}$ concentration of $3 \% \mathrm{v} / \mathrm{v}$. The statistical model was validated by comparing model predicted results with those of repeated experiments carried out at the optimised conditions. The mean of the results obtained from three replications was close to that predicted by the model thus showing validity.

\section{CONCLUSION}

Citric acid production from cocoyam starch via submerged fermentation using Aspergillus niger was investigated in this study. A three-variable, three-level Box-Behnken design was used to study the simultaneous effect of stimulants such as $\mathrm{Zn}^{2+}, \mathrm{Fe}^{3+}$, $\mathrm{CH}_{3} \mathrm{OH}$ on citric acid production. A statistically significant model $(\mathrm{p}<0.0001)$ was developed to describe the relationship between citric acid concentration and the chosen independent variables. The fermentation conditions were optimised using RSM. The statistical model showed a good fit with the experimental data $\left(\mathrm{R}^{2}=0.997\right)$ with a low standard deviation. High concentration of $\mathrm{Zn}^{2+}$, high concentration of $\mathrm{CH}_{3} \mathrm{OH}$ and intermediate concentration of $\mathrm{Fe}^{3+}$ were favourable for citric acid production. Citric acid production was positively influenced by $\mathrm{Zn}^{2+}$ and $\mathrm{CH}_{3} \mathrm{OH}$ while the reverse was the case for $\mathrm{Fe}^{3+}$. The optimum values of $\mathrm{Zn}^{2+}, \mathrm{Fe}^{2+}$ and $\mathrm{CH}_{3} \mathrm{OH}$ were $4.5 \mathrm{~g} / \mathrm{L}, 6.87 \mathrm{~g} / \mathrm{L}$ and $3 \% \mathrm{v} / \mathrm{v}$ respectively. Under these conditions, the citric acid concentration was obtained as $108 \mathrm{~g} / \mathrm{L}$.

\section{REFERENCES}

[1] Amenaghawon N.A., Osazuwa, O.U. and Okieimen, C.O. "Dynamic modelling and simulation of citric acid production from dilute acid hydrolysed corn starch using Aspergillus niger", Nigerian Journal of Technology, Vol. 33, Number 2, 2014, pp. 222-229.

[2] Kumar, A. and Jain, V.K. (2010). "Solid state fermentation studies of citric acid production", African Journal of Biotechnology, Vol. 7, Number 5, pp.644-650.

[3] Max, B., Salgado, J.M., Rodríguez, N., Cortés, S., Converti, A., and Domínguez, J.M. "Biotechnological production of citric acid", Brazilian Journal of Microbiology, Vol. 41, Number 4, 2010, pp. 862-875.

[4] Amenaghawon, N.A., Oronsaye, J.E and Ogbeide, S.E. "Statistical Optimisation of Fermentation Conditions for Citric Acid Production from Pineapple Peels",
Nigerian Journal of Technological Research, Vol. 9, Number 2, 2014, pp. 20-26.

[5] Kim, J.K. Optimization of Citric Acid Production by Aspergillus niger NRRL 567 in Various Fermentation Systems. PhD Thesis. Quebec, Canada: McGill University, 2004.

[6] FAO. Food outlook: Global market analysis. Food and Agriculture Organisation, Rome, Italy, 2009, p.28.

[7] Betiku, E. and Adesina, O.A. "Optimization of Sweet Potato Starch Hydrolyzate Production and Its Potential Utilization as Substrate for Citric Acid Production", British Biotechnology Journal, Vol. 3, Number 2, 2013, pp. 169-182.

[8] Kunamneni, A. and Singh, S. "Response surface optimization of enzymatic hydrolysis of maize starch for higher glucose production", Biochemical Engineering Journal, Vol. 27, 2005, pp. 179-190.

[9] Alvarez-Vasquez, F., Gonzalez-Alco, C. and Torres, N.V. "Metabolism of citric acid production by Aspergillus niger: Model definition, steady-state analysis and constrained optimization of citric acid production rate", Biotechnology and Bioengineering, 70, 2010, pp. 82-108.

[10] Ashraf, H., Rehman, A.U. and Haq, I.U. "Effect of alcohols on the production of citric acid by Aspergillus niger using solid state fermentation", Journal of Food Technology, Vol. 2, Number 1, 2004, pp. 1-3.

[11] Femi-Ola, T.O., Oluyege, J.O. and Gbadebo, A.O. "Production of citric acid from pineapple waste", Continental Journal of Microbiology, Vol. 3, 2009, pp. 1-5.

[12] Kumar, D., Jain, V.K., Shanker, G. and Srivastava, A. "Citric acid production by solid state fermentation using sugarcane bagasse", Process Biochemistry, Vol. 38, Number 12, 2003, pp. 1731-1738.

[13] Amenaghawon, N.A, Nwaru, K.I., Aisien, F.A., Ogbeide, S.E and Okieimen, C.O. "Application of BoxBehnken Design for the Optimization of Citric Acid Production from Corn Starch Using Aspergillus niger", British Biotechnology Journal, Vol. 3, Number 3, 2013, pp. 236-245.

[14] Fang, H., Zhao, C. and Song, X. "Optimization of enzymatic hydrolysis of steam-exploded corn stover by two approaches: Response surface methodology or using cellulase from mixed cultures of Trichoderma reesei RUT-C30 and Aspergillus niger NL02", Bioresource Technology, Vol. 101, 2010, pp. 4111-4119.

[15] Montgomery, D.C. Design and Analysis of experiments 6th ed., New York: John Wiley \& Sons, Inc., 2005.

[16] Tian, S., Wang, Z., Fan, Z. and Zuo, L. “Optimization of $\mathrm{CO}_{2}$ laser-based pretreatment of corn stover using response surface methodology", Bioresource Technology, Vol. 102, 2011, pp. 10493-10497. 
[17] Akpata, D.F. and Babalola, T.0. "The Use of Cassava, Sweet Potato and Cocoyam, and Their By-Products by Non-Ruminants", International Journal of Food Science and Nutrition Engineering, Vol. 2, Number 4, 2012, pp. 54-62

[18] Lotfy, W.A., Ghanem, K.M. and El-Helow, E.R. "Citric acid production by a novel Aspergillus niger isolate: II. Optimization of process parameters through statistical experimental designs", Bioresource Technology, Vol. 98, Number 18, 2007, pp.34703477.

[19] Marrier, J.R. and Boulet, M. "Direct Determination of Citric Acid in Milk with an Improved Pyridine-Acetic Anhydride Method", Journal of Dairy Science, Vol. 41, Number 12, 1958, pp. 1683-1692.

[20] Imandi, S.B., Bandaru, V.V.R., Somalanka, S.R., Bandaru, S.R. and Garapati, H.R. "Application of statistical experimental designs for the optimization of medium constituents for the production of citric acid from pineapple waste", Bioresource Technology, Vol. 99, Number 10, 2008, pp. 4445-4450.

[21] Amenaghawon, N.A., Osemwengie, S.O., Omoregbe, O. and Asogwa, U.J. "Application of experimental design method for the optimisation of xanthan gum production from pineapple peels using Xanthomonas campestris via submerged fermentation", Nigerian Journal of Technology, Vol. 34, Number 3, 2015, pp. 491-498.

[22] Hou, X.J. and Chen, W. "Optimization of extraction process of crude polysaccharides from wild edible Bachu mushroom by response surface methodology", Carbohydrate Polymers, 72, 2008, pp. 67-74

[23] Cao, G., Ren, N., Wang, A., Lee, D.J., Guo, W., Liu, B., Feng, Y. and Zhao, Q. "Acid hydrolysis of corn stover for biohydrogen production using
Thermoanaerobacterium thermosaccharolyticum W16", International Journal of Hydrogen Energy, Vol. 34, 2009, pp.7182-7188.

[24] Majolli, M.V. and Aguirre, S.N. "Effect of trace metals on cell morphology, enzyme activation, and production of citric acid in a strain of Aspergillus wentii. Revista Argentina de microbiologia, Vol. 31, Number 2, 1998, pp. 65-71.

[25] Hauka, F.I.A., El-Sawah, M.M.A., Kassem, M.M. and ElKady, S.M. "Some factors affecting citric acid production from sugar cane molasses by Aspergillus niger". In: The 2nd Arab Mansoura Conference on Food and Dairy Science and Technology, 22 - 24 March (2005), Mansoura University, Mansoura, Egypt

[26] Hang, Y.D. and Woodams, E.E. "Production of citric acid from corncobs by Aspergillus niger. Bioresource Technology", Vol. 65, Number 3, 1998, pp. 251-253.

[27] Soccol, C.R., Vandenberghe, L.P., Rodrigues, C. and Pandey, A. "New perspectives for citric acid production and application", Food Technology and Biotechnology, Vol. 44, Number 2, 2006, pp. 141-149.

[28] Alben, E. and Erkmen, O."Production of citric acid from a new substrate, undersized semolina, by Aspergillus niger", Food Technology and Biotechnology, Vol. 42, Number 1, 2004, pp. 19-22.

[29] El-Holi, M. A. and Al-Delaimy, S."Citric acid production from whey with sugars and additives by Aspergillus niger",African Journal of Biotechnology, Vol. 2, Number 10, 2004, pp. 356-359.

[30] Nadeem, A., Syed, Q., Baig, S., Irfan, H. and Nadeem, M."Enhanced production of citric acid by Aspergillus niger M-101 using lower alcohols”, Turkish Journal of Biochemistry, Vol. 35, Number 1, 2010, pp. 7-13. 